\title{
THE EFFECT OF GREEN PERCEIVED QUALITY, GREEN PERCEIVED RISK ON GREEN SATISFACTION AND GREEN TRUST ON THE BODY SHOP PRODUCT
}

\begin{abstract}
Erna S. Imaningsih
Economics and Business Faculty, Universitas Mercu Buana

ABSTRACT

The concept of green marketing as part of ethical marketing is growing not only in developed countries but begins to spread in developing countries. The success of green marketing implementation aimed at marketing environmentally safe products (greenness product) is indicated by the change of consumer behavior. This study intends to examine the effect of perceived quality and perceived risk if it is related to the green consumer behavior in Indonesia which is relatively new developing. The results of this study indicate that there is an influence of green perceived quality to green satisfaction and there is a green influence on green trust on Body Shop products in Indonesia.

Key words: Greenness Product Perception, green perceived quality, green perceived risk, green satisfaction, green trust

DOI: $10.7176 / \mathrm{JMCR} / 55-07$

Publication date: April $30^{\text {th }} 2019$

\section{INTRODUCTION}

Business activity in today's world faces tremendous challenges, as on the one hand facing climate change issues, water conservation, poverty reduction, human rights issues, fair business and support for local communities, on the other hand there are demands for profitability. Business is required not only to act ethically and responsibly to human beings and the environment but also productive and caring for the welfare and happiness of people and the environment as a whole.

Issues on social and environmental issues are now more important than others. There is no other way unless businesses are aware of these challenges by implementing sustainability strategies in their business processes and objectives and consumers are aware of the importance of changing their consumption behavior towards more environmentally friendly patterns. Loyal customers will generally continue to use the brand despite being faced with many alternative brands of competing products that offer superior product characteristics (Astini, Rina, 2016).
\end{abstract}

The increased environmental pollution due to industrial activity is also a major reason that makes consumers increasingly increase attention to environmental issues (Chen, 2011). This encourages companies to want to do environmental protection as a social responsibility (Peattie, 1995; Lee, 2009). The importance of environmental considerations related to the phenomenon of global warming encourages companies to compete to improve their ability to green opportunities (dwyer, 2009; Molina-Azorin et al., 2009). In the environmental context, companies pay more attention to green marketing in some products such as information and electronic products (Kalafatis and Pollard, 1999).

Along with the increasingly popular green products in the market, so is also with green marketing activity. In order to gain competitive advantage, the company uses a strategy to increase consumer perceived quality and reduce consumer perceived risk as a form of appreciation for the consumer's concern for the environment (Chen, 2010).

The efforts undertaken in green marketing activities include launching and promoting green products and services to satisfy the needs and wants of consumers without the impact of environmental damage (Polonsky, 1994). As one of the important elements that should be the priority of the company's green marketing strategy, perceived quality is an important factor in improving marketing performance (Parasuraman, 1996). Perceived quality is also a key factor in maintaining long-term relationships with consumers who raise the importance of purchasing intentions (Bruck 2000).

A purchase often involves risks particularly when the consequences of post purchase are uncertain (Rao et al 2007). Also in considering the purchase decision of green product, perceived risk is one important element, amid the uncertainty and lack of information about green product (Gershoff and Frels, 2015). Perceived risk is a 
subjective estimate by consumers associated with the possible consequences of wrong purchasing decisions (Peter, Ryan, 1972). Because perceived risk is a combination of uncertainty and negative consequences, perceived risk could affect consumer purchasing decisions (Aaker, 1996).

As an effort to reduce customer perceived risk, the company opens the widest possible access to information for consumers so that they can compare with other companies based on environmental function (Peattie, 1992). Without such information, it is difficult for companies to gain consumer confidence that the product is a green product.

In some countries like Japan, Europe, and America, there is a wave of awareness about the importance of consuming green products, thus it shapes new consumer behavior. But not so in developing countries, including Indonesia, there is still a slow development of green products and consumer behavior that show concern for the green concept. One of the consumer behavior issues on Indonesia green market is satisfaction and loyalty. Loyal customers will generally continue to use the brand despite being faced with many alternative brands of competing products that offer superior product characteristics (Astini, Rina, 2016).

On the other hand, despite a lot of research that examines issues related to trust (trust). The prior research about brand trust, recommend practitioner to pay attention the level to maintain the trust of the consumer, because it is important to influence the loyalty (Sihite et al, 2015). But not many that link environmental issues and brabd trust from the perspective of perceived quality and perceived risk. Based on Chen's findings, Chang, 2013, green perceived quality and green perceived risk affects green satisfaction and green trust for informatics and electronic products in Taiwan. This research intends to further develop with different object of research with previous research, that is in cosmetics industry. Beside, researcher also differentiates from method of analysis and statistic tool used to process data that is using PLS, as well as the research location. This study would like to see more green consumer developments in Indonesia.

The titles presented are: The Influence of Green Perceived Quality, Green Perceived Risk, and Green Satisfaction to the green trust in Body Shop products

\section{Formulation of the Problem}

1. Does green perceived quality affect the forming of green satisfaction?

2. Does green perceived risk affect the forming of green satisfaction?

3. Does green satisfaction affect the forming of green trust?

4. Does green perceived quality affect the forming of green trust?

5. Does green perceived risk affect the forming of green trust?

\section{Research purposes}

1. To know the effect of green perceived quality in forming green satisfaction.

2. To know effect of green perceived risk in forming green satisfaction.

3. To know the effect of green satisfaction in forming green trust.

4. To know the effect of green perceived quality in forming green trust.

5. To know the effect of green risk perceived in forming green trust.

\section{Benefits of the Research}

1. For Academics, the results of this study are expected to provide view and insight into the concept of consumer behavior into the realm of green marketing

2. For Business practitioners, the results of this research can be the basis for the implementation of green marketing activities as a competitive advantage of the company

3. For other Researchers, the results of this study are expected to be used as reference material and additional data for other researchers interested in this field of study.

\section{REVIEW OF THE LITERATURE}

\section{Green Marketing}

Green Marketing was first discussed in an eco-marketing seminar by the AMA (American Marketing Association) in 1975, analyzed the impact of marketing on the environment, studied the impact of losses and positive impacts on environmental pollution, energy consumption, and other sources of consumption as a result of marketing activities (Cevreorman, 2010 in Bozlepe, 2012).

The understanding of Green Marketing by American Marketing Associate (AMA, 1975): "Green Marketing is the marketing of products that are presumed to be environmentally safe" 
Green Perceived Quality

Perceived quality is defined as delivering value to the consumer through a purchase offer and deferring the product or brand of the competitor (Zeithaml, 1988, Aaker, 1996). Definition of Perceived Quality (Aaker, 1991): consumer perception of the overall quality or superiority of a product or service similar to the intended purpose.

While the dimensions of Perceived Quality by Aaker, 1991:

- Performance

- Serviceability

- Durability

- Reliability

- Feature

- Conformance with specification

- $\quad$ Fit and Finish

Company can improve product quality to achieve competitif advantage (Parasuraman et al 1988). Both practitioners and researchers should pay attention to the perceived quality effect on marketing performance in line with the increasing importance of perceived quality today (Sweeney et al, 1999). Because of the increasingly popular environmental concerns, researchers are proposing a new construct of green perceived quality that refers to Zeithaml (1988), defined as: consumer decisions about a product or brand are through superiority and environmental stewardship.

\section{Green Perceived Risk}

Purchasing decisions often involve risks particularly when the post-purchase consequences are uncertain (Rao et al 2007). Perceived risk, which is a subjective estimate by consumers, is related to the possible consequences of a wrong purchase decision (Peter, Ryan, 1972). "Green perceived risk" is defined as "expectations of negative environmental consequences associated with purchasing decisions" (Peter and Ryan 1976). Perceived risk is a combination of uncertainty and negative consequences, the perceived risk will affect consumer purchasing decisions (Aaker, 1996).

Green perceived risk : the expectation of negative environmental consequences associated with purchase behavior" (Chen, Chang 2013)).

The perceived risk dimensions are: Social risk, Economy risk, Privacy risk, Quality risk, After sale risk (Zhang, et al 2009).

\section{Green Satisfaction}

Geen Satisfaction: a pleasurable level of consumption-related fulfillment to satisfy a customer's environmental desires, sustainable expectations, and green needs".(Chen,2010). Dimensi : environmental desires, sustainable expectations,green needs (Chen, Chang 2013)

\section{Green Trust}

Green trust : a willingness to depend on a product, service, or brand based on the belief or expectation resulting from its credibility, benevolence, and ability about its environmental performance". (Chen, 2010). Dimensi : credibility, benevolence, ability (Chen, 2010)

\section{CONCEPTUAL FRAMEWORK}

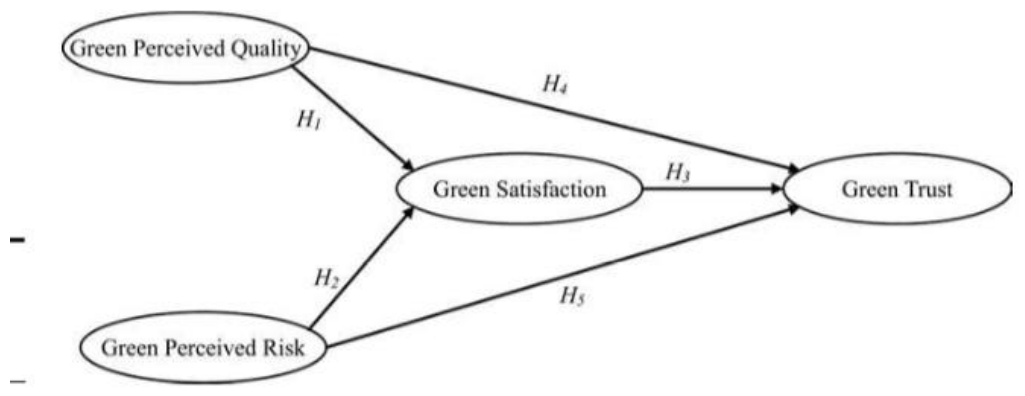

Figure 2.1 Conceptual Framework 


\section{HYPHOTHESIS DEVELOPMENT}

\section{The Effect of green perceived quality on green satisfaction}

Perceived quality is an important factor in improving marketing performance and can increase consumer satisfaction (Parasuraman, 1996). Research shows that there is a positive relationship between perceived quality and customer satisfaction because perceived quality can physically convey supplier competence and improve post-purchase confidence (Sweeney et al 1999, Tsiotsou, 2006). This shows that perceived quality of product or brand is positively related to consumer satisfaction (Eid, 2011). This research proposes a hypothesis:

H1: Green perceived quality is positively related to green satisfaction.

\section{The Effect of green perceived risk on green satisfaction}

Perceived risk is a combination of uncertainty and negative consequences, the occurrence of perceived risk will affect consumer purchasing decisions (Aaker, 1996).

The higher perceived risk is, the more consumers bet on their buying decisions. Mitchel 1996 shows that buying intention is negatively driven by perceived risk. Previous research has shown that risk reduction leads to increased purchasing possibilities (Wood, Scherr, 1996). A significant association between risk perceptions and negative consumption emotions will directly affect satisfaction (Chaudary, 1997). Since purchasing intention is negatively related to perceived risk, this study uses green purchase intention as a proxy for green satisfaction and argues that green perceived risk will negatively affect green satisfaction. Then the hypothesis proposed as follows;

$\mathrm{H} 2$ : Green perceived risk is negatively related to green satisfaction.

\section{The Effect of green satisfaction on green trust}

Customer satisfaction is an important limitation in determining long-term customer relationships (Zang and Prybutok, 2005). Furthermore, satisfaction is the result of an overall evaluation of economic conditions and psychological factors that can positively affect consumer relationships (Geysken et al, 1999). Consumer trust is therefore influenced by consumer satisfaction (Horppu et al, 2008). Previous research concludes that consumer satisfaction is a factor that affects trust. (Garbarino and Johnson, 1999, Yeh and Li, 2009). Therefore the next hypothesis yitu:

H3: Green satisfaction is positively related to green trust

\section{The Effect of green perceived quality on green trust}

If consumers accept that products are high quality, then they will tend to have high confidence in the product or brand (Garbarino, Johnson 1999). High perceived quality will improve not only customer satisfaction (Parasuraman, 1988) but also consumer trust (Garbario, Johnson, 1999). On the contrary less perceived quality will lower consumer trust (Yeh and Li, 2009). Therefore the proposed hypothesis is:

H4: Green perceived quality positively affects green trust

\section{The Effect of green perceived risk on green trust}

Perceived risk has a negative influence in the consumer buying process (Murphy and Enis, 1986), because it is a subjective expectation of a loss (Engel et al., 1986). This affects consumer behavior (Mitchel 1999). Past research indicates a reduced perceived risk will increase consumer trust (Koehn 2003). Based on previous research, it is generally accepted that perceived risk negatively affects perceived trust (Corritore et al 2003, Eid, 2011). Companies can reduce perceived risk to increase consumer trust (Warington et al 2000). The following hypothesis is proposed:

H5 : Green perceived risk negatively influences green trust

\section{RESEARCH METHODS}

The research design used by the author is associative causal. According to Sugiyono (2014), associative causal design is useful to analyze the relationship between one variable with other variables or how one variable affects other variables. In this study, to determine the effect of one or more exogenous variables on endogenous variables, hypothesis testing with statistical tests is needee in this case to know the effect .The population in this study is the consumer users of The Body Shop products, as products that represent the green product.

Sampling conducted in this research with technique of non probability sampling. Sampling method is done by purposive sampling method, according to Sugiyono (2014) Puposive Sampling is a technique of determining samples with certain considerations. Thus, the sample is not randomly drawn but determined by the investigator on the basis of certain considerations. The appropriate sample size in the study is between 30 to 500 according to Sekaran (2006). In making it easier for researchers to perform the process of data analysis, researchers will take 
a sample of 60 respondents. The sample in this study is taken by way of visiting and interviewing respondents who are considered suitable as a source of data that has bought The Body Shop products at least 2 times purchase in the last year.

\section{Data Collection Technique}

Interview Technique,

The methods of collecting data obtained are through question and answer directly (face to face) with the consumer. Interviews are used as data collection techniques if the researcher wants to do a preliminary study to determine the issues to be researched, and if the researcher wants to know the things of the respondent more deeply and the number of respondents is little or not (Sugiyono, 2014).

Quesioner Technique (questionnaire)

The methods of data collection conducted are through the distribution of questionnaires to consumers who have used The Body Shop products into the sample. Questionnaire contains the statements about the identity of respondents and research variables, to find the complete information of the issues discussed. The statement interval in this study is 1-5 with the anchor statement Strongly Disagree (SD) to Strongly Agree (SA).

\section{E. Data Analysis Method}

The data analysis method used in this research is Component or Variance Based Structural Equation Model where in the data processing, it uses Partial Least Square program (Smart-PLS) version 3.0 PLS. The test steps will be done as follows:

1) Evaluation of Measurement (outer) Model

Outer model is often called (outer relation or measurement model) defining how each indicator block corresponds to its latent variables.

a) Convergent Validity

The Convergent Validity Testing of each construct indicator, according to Chin in Ghozali (2014), an indicator is said to have good valid if its value is greater than 0.70 , while the loading factor is 0.50 to 0.60 , it can be considered sufficient. Based on this criteria when there is a loading factor below 0.60 , it will be dropped from the model.

b) Discriminant validity

Discriminant validity test, reflective indicator can be seen on cross-loading between indicator with its construct. An indicator is valid if it has the highest loading factor to the target construct compared to the loading factor to another construct. Thus, the latent contract predicts the indicators on their blocks are better than the indicators in the other blocks. Another method to view discriminant validity is to look at the square root of average variance extracted (AVE) value of each construct with the correlation between the construct and the other constructs in the model, it is said to have a good discriminant validity value.

c) Composite Reliability

Composite reliability test aims to test the reliability of the instrument in a research model. If all values of latent variables have composite reliability or cronbach alpha $\geq 0.7$ it means that the construct has good reliability or the questionnaire used as a tool in this research has been reliable or consistent.

\section{2) Structural Model Testing/Hypothesis Test (Inner Model)}

Inner model testing is the development of concept-based models and theories in order to analyze the relationship between exogenous and endogenous variables that has been described in the conceptual framework. Tests on the structural model is done by looking at the R-square value which is a goodness-fit model test.

The testing phase of the structural model (hypothesis test) is done with the following steps:

a) R-square Value

See the value of R-square which is a goodness-fit model test. The second test can be seen from the results of $\mathrm{R}$ squre for endogenous latent variables of $0.67,0.33$ and 0.19 in the structural model indicating that the model is "good", "moderate", and "weak".

b) Goodness of Fit Model

The structural Goodness of Fit model test in inner model using predictive-relevance (Q2) value. A larger $Q$ square value of 0 (zero) indicates that the model has a predictive relevance value.

c) Hypothesis Testing Result (Line Coefficient Estimation)

The estimated value for the path relation in the structural model should be significant. This value of significance can be obtained by boostrapping procedure. See the significance of the hypothesis is by looking at the value of 
the parameter coefficient and the significance value of T-statistic on the algorithm boostrapping report the value of T-statistical significance should be more than 1,96 .

\section{RESULTS AND DISCUSSION}

Hypothesis Testing Result (Line Coefficient Estimation)

The estimated value for path relation in structural model should be significant. This value of significance can be obtained by boostrapping procedure. See the significance of the hypothesis is by looking at the value of the parameter coefficient and the significance value of t-statistics on the algorithm boostrapping report. To know whether it is significant or not significant, it is seen from t-table at alpha $0,05(5 \%)=1.96$, then t-table is compared by t-hitung (t-statistic). Or it can also compare the value of $\mathrm{P}$ value with alpha 0.05 , if $\mathrm{p}$ value is smaller than alpha (0.05) then the hypothesis is accepted.

Table 4.1

Hypothesiss Testing Result

\begin{tabular}{|c|c|c|c|c|c|}
\hline & & $\begin{array}{l}\text { Original } \\
\text { Sample }\end{array}$ & $\stackrel{t-}{\text { Statistics }}$ & $\begin{array}{c}\text { p } \\
\text { Values }\end{array}$ & Explanation \\
\hline H1 & $\begin{array}{l}\text { Green perceived quality }>>\text { green } \\
\text { satisfaction }\end{array}$ & 0.378 & 3.082 & 0.002 & positive -significant \\
\hline$H 2$ & Green perceived risk >> green satisfaction & 0.065 & 0.419 & 0.676 & positive - not significant \\
\hline$H 3$ & green satisfaction $>>$ green trust & 0.486 & 3.847 & 0.000 & positive -significant \\
\hline H4 & Green perceived quality $>>$ green trust & 0.026 & 0.107 & 0.915 & positive - not significant \\
\hline$H 5$ & Green perceived risk >> green trust & -0.156 & 0.860 & 0.390 & negative - not significant \\
\hline
\end{tabular}

Source : output PLS

Figure 4.1

Boostrapping Structural Model

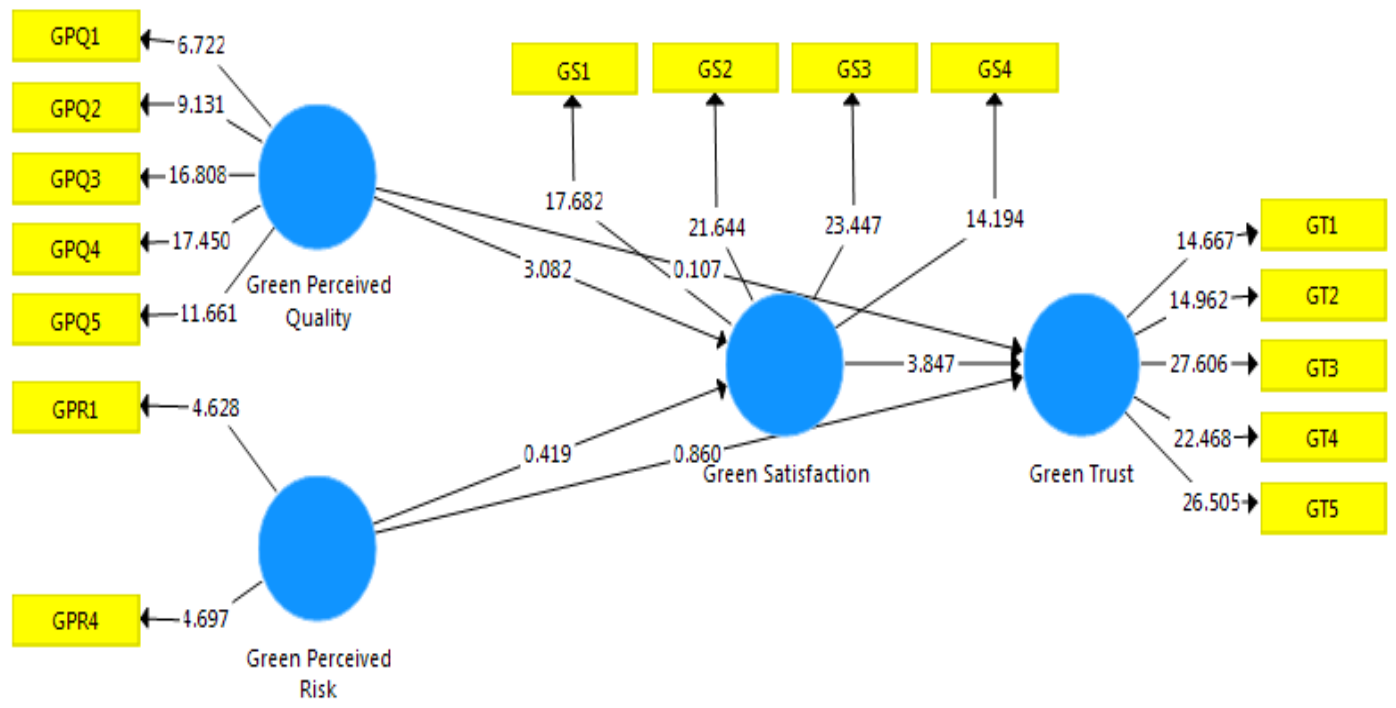

\section{Result Analysis}

Based on the results of structural equation modeling analysis above, not all hypotheses prepared by researchers proved true. Only two positive relationships are significant between the complex variables of each hypothesis.

\section{The Effect of Green Perceived Quality in forming Green Satisfaction}

Based on the hypothesis test in this study, it is shown that Green Perceived Quality gave positive and significant influence in forming Green Satisfaction. The data show t statistic of 3.082 and probability of 0.002 where the value indicates a positive and significant relationship. Thus, it can be concluded that the influence of green perceived quality positively affects green satisfaction. The results of this hypothesis is strengthened by the 
research of Chen and Chang (2013) that proves Green Perceived Quality has positive and significant effect on Green Satisfaction.

The Effect of Green Perceived Risk in forming Green Satisfaction

Based on the hypothesis test in this study, it shows that $\mathrm{t}$ statistic for the relationship between green perceived risk and green satisfaction is 0,419 and probability value 0,676 , which means that Green Perceived Risk has no influence in forming Green Satisfaction. The results of this hypothesis is different from the research conducted by Chen and Chang (2013) whose result in research states that Green Perceived Risk has negative effect on Green Satisfaction.

\section{The Effect of Green Satisfaction in forming Green Trust}

Based on the hypothesis test in this study, it shows the result $t$ statistic of 3.847 and probability of 0.000 . This shows that Green Satisfaction has a positive and significant influence in forming Green Trust. The results of this hypothesis are reinforced by previous research conducted by Horppu et al, (2008) who found that consumer trust is influenced by customer satisfaction. In addition, the results of research conducted by Garbarino and Johnson, (1999), Yeh and Li, (2009) concluded that consumer satisfaction is trust antecedents.

\section{The Effect of Green Perceived Quality in forming Green Trust}

Based on the hypothesis test in this study, it shows $t$ statistical results for the relationship between green perceived quality and green trust of 0.107 and probability value of 0.915 . This means that Green Perceived Quality has no influence in forming Green Trust. The results of this hypothesis is different from the research conducted by Chen and Chang (2013) results in research which states that Green Perceived Quality positively affect Green Trust.

\section{CONCLUSIONS}

The results of this study show there are two proven hypotheses that there is a positive and significant influence of green perceived quality to green satisfaction. Furthermore, Green Satisfaction that occurs gives a positive and significant influence in forming Green Trust.

Establishing customer satisfaction and trust is the company's goal in its marketing strategy. From the result of research, it is also known that green satisfaction is influenced by green perceived value. And green satisfaction affects consumer's green trust. Thus, it can be said that the higher green perceived value is, the higher the consumer's green trust will be.

\section{SUGGESTIONS}

The research should be done in some other big city areas not only Jakarta, so it is not homogeneous and concentrated in certain city or region only. It should also be done in other industries, for example organic food product or electronic product to see how big the role of green marketing program in forming consumer perception to green perceived value and green behavior. It needs further research on green marketing as a new marketing program concept applied in Indonesia providing there is still low awareness of consumers and community about the importance of green concept in consumption behavior.

\section{REFERENCES}

Aaker, David A, 1991. Managing Brand Equity : Capitalizing on The Value of a Brand Name, New York; The Free press

Adebowale Akande, 2009, Comparing Social Behaviour across Culture and Nations: The 'What' and 'Why' Questions, Social Indicators Research

Arnould, Thompson, 2005, Consumer Culture Theory (CCT): Twenty Years of Research, Journal Consumer Research

Astini, Rina, 2016, Implikasi Green Brand Image, Green Satisfaction, dan Green Trust on Consumer Loyalty, Jurnal Manajemen/Volume XX, No. 01, Februari 2016: 19-34

Barr, et al, 2007, A Conceptual Framework for Understanding and Analyzing Attitudes towards Environmental

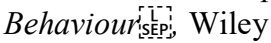

Balqiah, Tengku Ezni Rifelly Dewi Astuti, 2013, The Role of Green CSR and Corporate Ethics in Enhancing Customer Trust and Society's Quality of Life, Universitas IndonesiaCarrington,

Michal J., Neville, Benjamin A. and Whitwell, Gregory J., 2010, Why Ethical Consumers Don't Walk Their Talk: Towards a Framework for Understanding the Gap Between the Ethical Purchase Intentions and Actual Buying Behaviour of Ethically Minded Consumers, Journal of Business Ethics

Chan, Ricky Y. K. Y. H. Wong and T. K. P. Leung., 2008, Applying Ethical Concepts to the Study of "Green" 
Consumer Behavior: An Analysis of Chinese Consumers' Intentions to Bring Their Own Shopping Bags, Journal of Business Ethics

Gershoff \& Frels, 2015 What makes It Green? The Role of Centrality of GreenAtributes in Evaluation of Greenness of Product

Ghozali, Imam. 2014. Structural Equation Modeling : metode alternative dengan Partial Least Square (PLS). Badan Penerbit, Universitas Diponegoro Semarang.

Hawkins, 2010, $11^{\text {th }}$ ed, Consumer Behavior, Mc Graw- Hill

Kotler Philip and Keller, Kevin L, 2009. Marketing Management 13 th edition New Jersey: Pearson-Prentice Hall

Kotler, Philip,2002. Marketing Management 3th edition Singapore: Prentice Hall, IncKeller, Kevin Lane, 2008, Strategic Brand Management: Building, Measuring,and Managing Brand Equity, New Jersey: PearsonPrentice Hall

Kotler Philip and Keller, Kevin L, 2009. Marketing Management 13 th edition New Jersey:Pearson-Prentice Hall

Kareklas, Carlson, Muehling, 2013, I eat organic for my benefit and Yours : Egoistic and Alturuistic consideration for Purchasing organic Food an their Implications fo advertising Srategies

Papista, Erifili ; Krystallis Athanasios, 2013, Investigating the Types of Value and Cost of Green Brands: Proposition of a Conceptual Framework, jornal of Business Ethic

Sing, Satyendra Demetris Vrontis d..., 2011, Green Marketing and Consumer Behavior : The Case of Gasoline Products, Taylor\&Francis Group

Sihite Janfry, Tabby Wihasari Harun, Arissetyanto Nugroho, 2015 The Low Cost Airline Consumer Price Sensitivity. An Investigation on The Mediating Role of Promotion and Trust in Brand, International Research Journal of Business Studies vol. VII no. 03

Rowlands, Ian Paul Parker Daniel Scott, 2002, Consumer perceptions of "green power”, Journal of Consumer Marketing, Solomon, 2013, Consumer Behavior, $10^{\text {th }}$ ed, Pearson

Wijanto, Setyo Hari. (2015). Metode penelitian menggunakan Structural Equation Modeling dengan LISREL 9.1, Lembaga Penerbit Fakultas Ekonomi Universitas Indonesia. Jakarta.

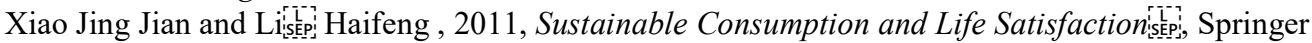

Yu-Shan Chen 2010 , The Drivers of Green Brand Equity: Green Brand Image, Green Satisfaction, and Green Trust, Journal of Business Ethics

Rashad Yazdanifard, Igbazua Erdoo (2011) The impact of Green Marketing on Customer satisfaction and Environmental safety, International Conference on Computer Communication and Management Proc of CSIT vol.5 IACSIT Press, Singapore

Yu-Shan Chen Ching-Hsun Chang (2013). Towards green trust: The influences of green perceived quality, green perceived risk, and green satisfaction,Management Decision, Vol. 51 Yu-Shan Chen Ching-Hsun Chang, (2012), "Enhance green purchase intentions", Management Decision, 